\title{
SOWING SEASONS AND QUALITY OF SOYBEAN SEEDS
}

\author{
Marizangela Rizzatti Ávila'; Alessandro de Lucca e Braccini1 ${ }^{13 *}$; Ivo de Sá Motta ${ }^{1}$; Carlos \\ Alberto Scapim ${ }^{1,3}$; Maria do Carmo Lana Braccini ${ }^{2}$ \\ ${ }^{l}$ UEM - Depto. de Agronomia, Av. Colombo, 5790 - 87020-900 - Maringá, PR - Brasil. \\ ${ }^{2}$ UNIOESTE - Depto. de Agronomia, R. Pernambuco, 1777 - 85960-000 - Marechal Cândido Rondon, PR - Brasil. \\ ${ }^{3} \mathrm{CNPq}$ scholar. \\ *Corresponding author <albraccini@uol.com.br>
}

\begin{abstract}
Considering the difficulties of producing high quality soybean [Glycine max (L.) Merrill] seeds during the traditional cropping period in some areas of the State of Paraná, Brazil, a research project was carried out with the objective of evaluating the influence of sowing dates on the physiological and sanitary quality of seeds, during the 1998/99 and 1999/00 cropping seasons, in Maringá, PR, Brazil. The experiment consisted of five cultivar competition assays, arranged in a completely randomized block design, with each assay sown at different dates $(10 / 15,10 / 30,11 / 15,11 / 30$ and 12/15) for each cropping season. The evaluated cultivars were BRS 132 (early), BRS 133 (semi-early), BR 16 (semi-early), BRS 134 (intermediate) and FT- Estrela (late). Seeds obtained at the sowing dates were evaluated in the laboratory by germination, accelerated aging, and health tests. Sowing in November resulted in seeds with superior physiological and health quality. Cultivar BRS 133 showed the greatest stability in seed production with better quality for the different sowing dates. Cultivars BRS 134 and BRS 133, which were sown during the period from 10/15 to 11/30, produced seeds that had higher percentages of normal seedlings in the germination and accelerated aging tests. Advancing or delaying sowing dates had adverse effects on soybean seed production with regard to their sanitary quality.

Key words: cropping, cultivar, germination, health
\end{abstract}

\section{ÉPOCAS DE SEMEADURA E QUALIDADE DE SEMENTES DE SOJA}

\begin{abstract}
RESUMO: Considerando as dificuldades encontradas na produção de sementes de soja [Glycine max (L.) Merrill] com alta qualidade, na época de cultivo tradicional, em algumas regiões do Estado do Paraná, foi realizado um trabalho com o objetivo de avaliar a influência da época de semeadura na qualidade fisiológica e sanitária das sementes de cinco cultivares de soja, em dois anos agrícolas 1998/99 e 1999/00, na região de Maringá - PR. O experimento foi constituído de cinco ensaios de competição de cultivares com delineamento em blocos completos casualizados, semeando-se um ensaio em cada época de semeadura (15/10,30/10,15/11, 30/11 e 15/12) e anos agrícolas. Os cultivares avaliados foram: BRS 132 (precoce), BRS 133 (semiprecoce), BR 16 (semiprecoce), BRS 134 (médio) e FT- Estrela (tardio). Em laboratório, a qualidade das sementes provenientes das épocas de semeadura foram avaliadas pelos testes de germinação, envelhecimento acelerado $\left(41^{\circ} \mathrm{C}\right.$ por 48 horas) e sanidade (método do papel-filtro). A semeadura realizada em novembro foi mais favorável à obtenção de sementes de melhor qualidade fisiológica e sanitária. O cultivar BRS 133 apresentou maior estabilidade na produção de sementes de melhor qualidade nas diferentes épocas de semeadura avaliadas. Os cultivares BRS 134 e BRS 133, que foram semeados de 15/10 a 30/11, produziram sementes que apresentaram as maiores porcentagens de plântulas normais nos testes de germinação e de envelhecimento acelerado. Tanto a antecipação quanto o retardamento da época de semeadura foram desfavoráveis à produção de sementes de soja com relação à qualidade sanitária.

Palavras-chave: cultivo, cultivar, germinação, sanidade
\end{abstract}

\section{INTRODUCTION}

Soybean cropping in Brazil has great social and economic value, since it is important for bran production, alternative proteic foods (milk and textured protein) and high quality cooking oil, in addition to representing a considerable source of hard currency when exported to other countries. However, to obtain higher yields per unit area, the use of good quality seeds with high genetic potential, as well as the adop- tion of adequate cropping techniques, are crucial (Fraga, 1980).

Soybean development is influenced by several environmental factors, such as temperature, precipitation, relative humidity, soil moisture and, particularly, photoperiod. Considering the variation of these factors along the year and the soybean response to this variation, no other individual cropping factor influences soybean development and production so much as the sowing season (Rocha et al., 1996; Marcos Filho, 1986). 
Establishing the most adequate sowing season for the production of seeds with high physiological and sanitary quality depends on a number of factors, especially the genetic characters of the cultivars and the climatic conditions predominant in the region where they are planted. Among the most important factors that affect the physiological quality of soybean seeds stand the adequate definition of the sowing season, the determination of the most suitable regions for seed production, the use of high-quality-seed cultivars, harvesting at the right time, mechanical damage, insect attack, infection caused by microorganisms and inadequate storage (Costa et al., 1995).

The determination of the most suitable regions for soybean seed production can be made by gathering information and then establishing an appropriate ecological zoning. By doing several surveys on quality and later correlating the information with climatic data, Costa et al. (1992) prepared the ecological zoning for the production of early cultivar soybean seeds in the State of Paraná. According to this zoning, the municipal district of Maringá has been rated as medially favorable.

The period soybean seeds remain in the field after reaching physiological maturity is an important deterioration factor, caused especially by an increase in the incidence of pathogens or by a reduction in germination and vigor. Soybean seeds from late cultivars that reach maturation after the period when the weather is hot and dry, exhibit greater vigor than seeds from early cultivars that undergo maturation during hot and dry weather (Green et al., 1965). Therefore, using cultivars that have high-quality seeds, together with choosing regions that have more favorable climatic characteristics, as well as staggering the sowing dates, can surely result in the production of seeds with better physiological quality and low deterioration rates, with higher yields in the commercial exploration of the crop.

This deterioration process has been characterized as inexorable and irreversible (Delouche, 1982). Such process is determined by genetic factors, insect attack, environmental conditions in the post-maturation/pre-harvest period, harvesting and processing procedures, in addition to storage and transportation conditions.

The rate of reduction in seed germination and vigor varies in consonance with the sowing season as well as temperature, relative humidity and rainfall conditions during the maturation and harvest stages (Tekrony et al., 1980). Based on these studies, the authors suggest that sowing late-cycle cultivars, and by delaying the planting, operation, it may be possible to condition soybean plants to a more favorable climatic regime for the production of high-quality seeds.

Research projects have been carried out in many soybean-producing areas in the country, to establish the most adequate sowing season for the production of seeds with high physiological and sanitary quality (Melhorança \& Mesquita, 1982; Nakagawa et al., 1983). Because of the country's rather extense territory, within which very distinct edaphic and climatic conditions can be found, as well as to the expansion of the soybean crop towards other producing regions with the frequent introduction of more productive and better adapted cultivars, conducting this type of research becomes quite important.

Consequently, the objective of the present work was to evaluate the influence of different sowing dates on the physiological and sanitary quality of seeds of five soybean cultivars, produced during two cropping seasons in the northwest region of the State of Paraná.

\section{MATERIALS AND METHODS}

The present work was carried out during the 1998/99 and 1999/00 cropping seasons, at Maringá, PR, Brazil $\left(23^{\circ} 25^{\prime} \mathrm{S} ; 51^{\circ} 57^{\prime} \mathrm{W}\right)$ with seeds of five soybean cultivars: BRS 132 (early), BRS 133 (semi-early), BR 16 (semi-early), BRS 134 (intermediate) and FT-Estrela (late). The precipitation, maximum and minimum daily temperatures, and relative humidity data corresponding to the periods during which the assays were carried out, for both cropping seasons, are presented in Figure 1.

The soil at the location is a Red Eutroferric Nitosol, with a gentle rolling topography and mean slope of 4\%. By Köeppen's classification, the local climate is characterized as "Cfa", subtropical humid, mesothermic, with a hot summer, with a tendency to concentrate the rainfall in the summer period, but without a defined dry season (Fundação Instituto Agronômico do Paraná, 1987).

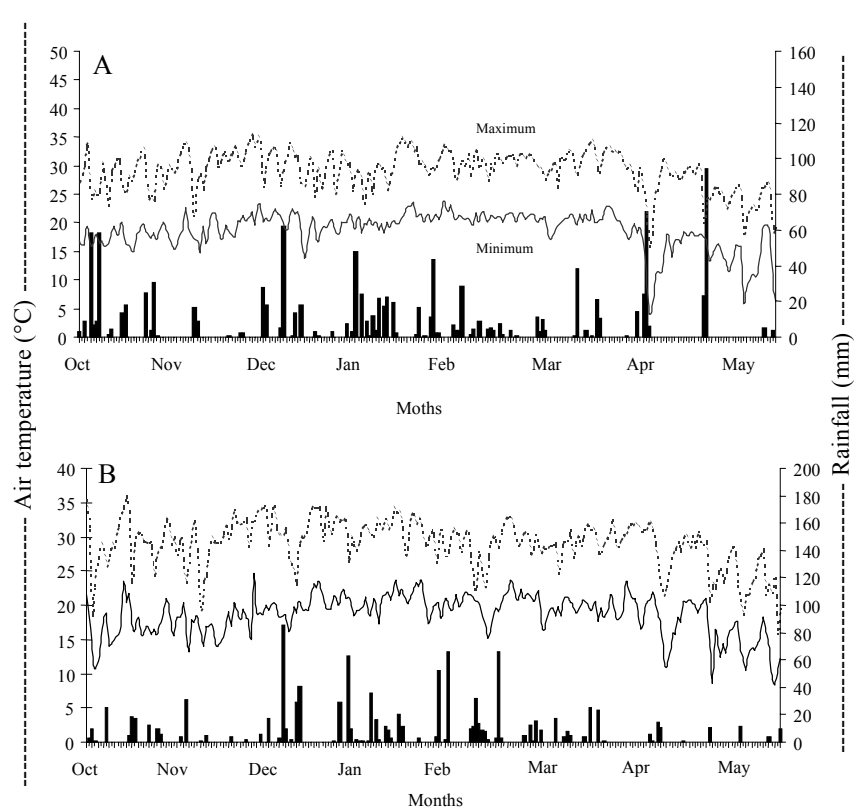

Figure 1 - Rainfall and daily maximum and minimum temperatures observed along the experimental period, during the 1998/ 99 (A) and 1999/00 (B) cropping seasons. 
Trials were set up with five treatments and three replicates, in a completely randomized block design, with sowings at dates: 10/15, 10/30,11/15, 11/30 and 12/15, of the 1998/99 and 1999/00 cropping seasons. Fertilization was made according to technical recommendations for the soybean crop, by analyzing the soil chemical characteristic. Forty seeds per linear meter were utilized at sowing, and thinning was made two weeks after plants emerged, when about 20 plants were left per rows linear meter.

Weeds were controlled by hand-weeding; caterpillars and insects were controlled as often as necessary, with sprays of Endosulfan, at a rate of $0.25 \mathrm{~L} \mathrm{ha}^{-1}$ for caterpillars and $1.00 \mathrm{~L} \mathrm{ha}^{-1}$ for insects, until the physiological maturation stage was reached $\left(\mathrm{R}_{7}\right)$.

The plots consisted of four rows, $5 \mathrm{~m}$ in length, spaced $0.5 \mathrm{~m}$. At harvest the two external rows were eliminated, as well as $0.5 \mathrm{~m}$ from each end of the central rows, considered as borders.

Plants were harvested by hand, five to eight days after reaching the $\mathrm{R}_{8}$ development stage, i.e., when $95 \%$ of the pods showed the typical coloration of a mature pod (Fehr et al., 1971). After harvesting, seeds were threshed from the pods in a stationary threshing machine, cleaned with the use of sieves, shade-dried, placed into paper bags, and maintained in cold storage at a temperature of $10^{\circ} \mathrm{C}$ and $50 \%$ R.H., until the end of the harvest and beginning of the seed quality evaluations. This evaluation was made by determining their water content, and performing germination, accelerated aging and health tests. Water content (Table 1) was determined by the oven method, at $105 \pm 3^{\circ} \mathrm{C}$ for 24 hours (Brasil, 1992).

Germination test was carried out utilizing four 50seed analytical replicates for each field replicate, placed to germinate between three paper towel sheets, soaked with demineralized water in a weight three times the weight of the dry paper towel. Rolls were prepared and taken to the germinator, kept at constant temperature $(25$ $\pm 1^{\circ} \mathrm{C}$ ). Assessments were performed at five (first count) and eight days (final count), by computing the percent- age of normal seedlings, according to the criteria established in "Regras para Análise de Sementes" (Brasil, 1992)

Accelerated aging test was carried out using four subsamples of 50 seeds for each treatment and field replicate, distributed over a piece of screen placed inside gerbox-type plastic boxes. To each box, $40 \mathrm{~mL}$ distilled water were added to form a humid chamber, and $45 \mathrm{~g}$ of seeds were placed on the screen. Boxes were then closed and taken to a BOD-type germination incubator, set at a temperature of $41^{\circ} \mathrm{C}$, for 48 hours, according to recommendations of Marcos Filho (1999). After the aging period, seeds were submitted to the germination test, as previously described, and the assessment was made on the fifth day after sowing.

Seed health test was performed by the filter paper method, utilizing 100 seeds, divided into four subsamples of 25 seeds placed in gerbox-type plastic boxes, on four sheets of filter paper, sterilized and moistened with distilled and autoclaved water. Incubation was performed in the laboratory under room conditions, at a temperature of approximately $25^{\circ} \mathrm{C}$, with 12 hours of light provided by fluorescent bulbs, and 12 hours of darkness, for seven days. After this period, fungi present on seeds were evaluated, with the use of a magnifying glass and a stereoscopic microscope (Henning, 1994; Goulart, 1997).

The experimental design consisted of random blocks with three field replicates, and each sowing season consisted of an individual cultivar competition assay of two cropping seasons, 1998/99 and 1999/00. Data were submitted to a joint analysis of variance, and when significant interactions were found the necessary partitioning was performed. The means were compared by the Scott-Knott (1974) clustering test to evaluate the effects of cultivars, and by regression analysis to investigate the behavior of traits in different sowing seasons, for each cultivar and cropping season, at the $5 \%$ level. The joint analysis of data was feasible for the five sowing seasons and in both cropping seasons, after the $\chi^{2}$ test at $5 \%$ was applied, according to recommendations of Gomes \& Gomes (1984).

Table 1 - Seed water content, in percent wet basis, of five soybean cultivars, for five sowing dates, during the 1998/99 and 1999/00 cropping seasons.

\begin{tabular}{|c|c|c|c|c|c|c|c|c|c|c|c|c|}
\hline \multirow{3}{*}{ Cultivar } & \multicolumn{5}{|c|}{ 1998/99 Cropping season } & \multirow{3}{*}{ Mean } & \multicolumn{5}{|c|}{ 1999/00 Cropping season } & \multirow{3}{*}{ Mean } \\
\hline & \multicolumn{5}{|c|}{ Sowing date } & & \multicolumn{5}{|c|}{ Sowing date } & \\
\hline & $10 / 15$ & $10 / 30$ & $11 / 15$ & $11 / 30$ & $12 / 15$ & & $10 / 15$ & $10 / 30$ & $11 / 15$ & $11 / 30$ & $12 / 15$ & \\
\hline BRS 132 & 9.69 & 8.03 & 9.76 & 8.26 & 8.09 & 8.77 & 9.08 & 9.97 & 9.08 & 8.95 & 8.98 & 9.21 \\
\hline BRS 133 & 9.51 & 8.20 & 8.96 & 8.37 & 8.17 & 8.64 & 9.22 & 8.99 & 9.09 & 8.97 & 8.98 & 9.05 \\
\hline BRS 134 & 9.51 & 8.23 & 8.92 & 8.31 & 8.23 & 8.64 & 9.17 & 9.02 & 9.18 & 9.13 & 9.14 & 9.12 \\
\hline BR 16 & 9.70 & 7.68 & 9.87 & 8.42 & 8.30 & 8.79 & 9.26 & 9.19 & 9.14 & 9.36 & 9.26 & 9.24 \\
\hline FT-Estrela & 8.65 & 8.04 & 9.36 & 8.36 & 8.39 & 8.56 & 9.39 & 9.10 & 9.27 & 9.83 & 9.67 & 9.45 \\
\hline Mean & 9.41 & 8.04 & 9.37 & 8.34 & 8.24 & & 9.22 & 9.05 & 9.14 & 9.24 & 9.19 & \\
\hline
\end{tabular}




\section{RESULTS AND DISCUSSION}

Interaction effect was detected $(P<0.05)$ for the cultivars $\mathrm{x}$ sowing seasons $\mathrm{x}$ cropping seasons, for the traits physiological and sanitary quality of the seeds, indicating a differential response by the cultivars to different sowing and cropping seasons. Great variability in soybean cultivar behavior can be observed, relative to seed quality, for the different sowing dates and cropping seasons (Tables 2 and 3). Cultivars BRS 133 and BRS 134 had a superior performance relative to the others in both cropping seasons, showing better seed quality for most sowing seasons.
November was the most favorable sowing time for obtaining better quality seeds in the region of Maringá, PR, for all cultivars (Tables 2 to 3). The highest seed germination and vigor percentages were obtained in this sowing period. These results can be explained because of the lower incidence of microorganisms during this period (Tables 4 and 5), which could have occurred because of the more favorable climatic conditions (Figure 1); results similar to this were obtained in other analogous studies (Nakagawa et al., 1983; Costa et al., 1995).

According to the regulations for seed production in force at the State of Paraná (Paraná, 1986), the minimum acceptable germination is $80 \%$. Considering com-

Table 2 - Normal seedling percentage means obtained for the first and final counts of the seed germination test of five soybean cultivars, for five sowing dates, during the 1998/99 and 1999/00 cropping seasons.

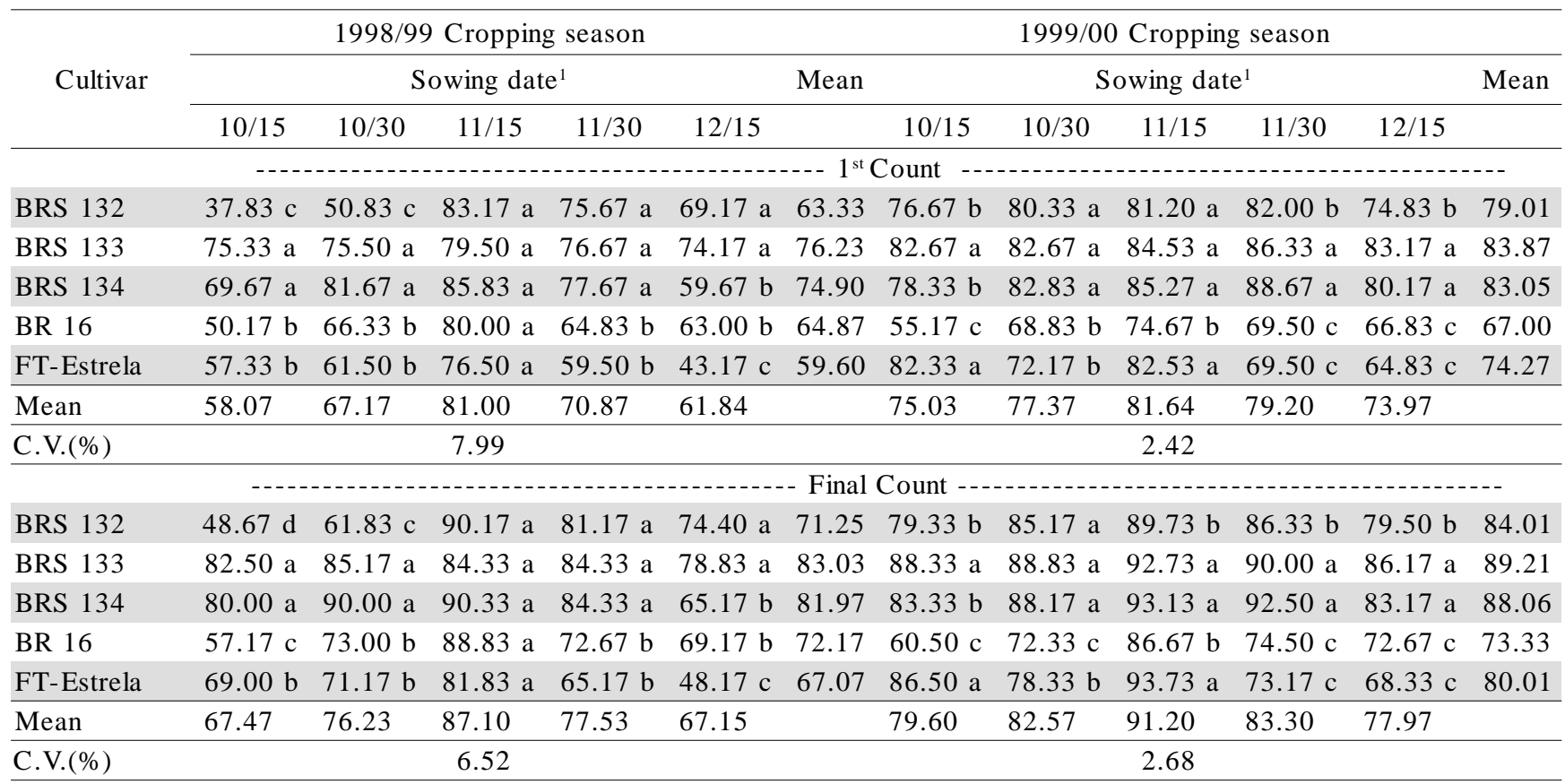

${ }^{1}$ Means followed by a common letter, in each column, belong to the same group, according to the Scott-Knott (1974) clustering criterion, at $5 \%$.

Table 3 - Normal seedling percentage means obtained for the accelerated aging test of seeds of five soybean cultivars, for five sowing dates, during the 1998/99 and 1999/00 cropping seasons.

\begin{tabular}{|c|c|c|c|c|c|c|c|c|c|c|c|c|}
\hline \multirow{3}{*}{ Cultivar } & \multicolumn{5}{|c|}{ 1998/99 Cropping season } & \multicolumn{7}{|c|}{ 1999/00 Cropping season } \\
\hline & \multicolumn{5}{|c|}{ Sowing date ${ }^{1}$} & Mean & \multicolumn{5}{|c|}{ Sowing date ${ }^{1}$} & \multirow[t]{2}{*}{ Mean } \\
\hline & $10 / 15$ & $10 / 30$ & $11 / 15$ & $11 / 30$ & $12 / 15$ & & $10 / 15$ & $10 / 30$ & $11 / 15$ & $11 / 30$ & $12 / 15$ & \\
\hline BRS 132 & $37.00 \mathrm{c}$ & $54.00 \mathrm{c}$ & $84.00 \mathrm{a}$ & $74.33 \mathrm{a}$ & $76.50 \mathrm{a}$ & 65.17 & $72.50 \mathrm{~b}$ & $83.83 \mathrm{a}$ & $82.87 \mathrm{a}$ & $82.17 \mathrm{a}$ & $81.83 \mathrm{a}$ & 80.64 \\
\hline BRS 133 & $67.67 \mathrm{a}$ & $78.83 \mathrm{a}$ & $77.00 \mathrm{~b}$ & $78.50 \mathrm{a}$ & $75.17 \mathrm{a}$ & 75.43 & $82.17 \mathrm{a}$ & $87.00 \mathrm{a}$ & $86.07 \mathrm{a}$ & $83.50 \mathrm{a}$ & $83.17 \mathrm{a}$ & 84.38 \\
\hline BRS 134 & $66.83 \mathrm{a}$ & $82.00 \mathrm{a}$ & $84.00 \mathrm{a}$ & $79.33 \mathrm{a}$ & $61.00 \mathrm{~b}$ & 74.63 & $74.50 \mathrm{~b}$ & $86.87 \mathrm{a}$ & $87.40 \mathrm{a}$ & $85.50 \mathrm{a}$ & $83.67 \mathrm{a}$ & 83.59 \\
\hline BR 16 & $49.67 \mathrm{~b}$ & $61.83 \mathrm{~b}$ & $87.17 \mathrm{a}$ & $70.50 \mathrm{a}$ & $71.83 \mathrm{a}$ & 68.20 & $70.50 \mathrm{~b}$ & $74.33 \mathrm{c}$ & $83.33 \mathrm{a}$ & $69.00 \mathrm{~b}$ & $66.83 \mathrm{~b}$ & 72.80 \\
\hline FT-Estrela & $62.17 \mathrm{a}$ & $68.33 \mathrm{~b}$ & $73.67 \mathrm{~b}$ & $69.17 \mathrm{a}$ & $44.33 \mathrm{c}$ & 63.53 & $70.00 \mathrm{~b}$ & $80.33 \mathrm{~b}$ & $84.53 \mathrm{a}$ & $73.33 \mathrm{~b}$ & $66.33 \mathrm{~b}$ & 74.90 \\
\hline Mean & 56.67 & 69.00 & 81.17 & 74.37 & 65.77 & & 73.93 & 82.47 & 84.84 & 78.70 & 76.37 & \\
\hline C.V.(\%) & & & 8.68 & & & & & & 3.58 & & & \\
\hline
\end{tabular}

${ }^{1}$ Means followed by a common letter, in each column, belong to the same group, according to the Scott-Knott (1974) clustering criterion, at $5 \%$. 
mercial standards, only the seeds obtained from sowing on $11 / 15$ were within the acceptable minimum conditions, for all cultivars and both cropping seasons (Table 2). With regard to the most promising cultivars, it was observed that BRS 133 and BRS 134 reached this standard in practically all sowing seasons, except on $12 / 15$ during the $1998 / 1999$ season, when the amount of rainfall and the consequent high incidence of pathogens affected production quality. These cultivars showed the lowest percentages of incidence of pathogenic microorganisms (Table 4).

During the first cropping season, the seeds obtained from cultivars BRS 133 and BRS 134, planted in October, had greater vigor (Table 3 ). Cultivars BRS 132, BRS 134 and BR 16 showed the best trial results for the $11 / 15$ planting, while for the $11 / 30$ planting there was no significant difference between cultivars. On the other hand, the cultivars that had the best late planting performance (12/15) were BRS 132, BRS 133 and BR 16. During the second cropping season, however, for the advanced planting (10/15), only seeds from cultivar BRS 133 showed higher vigor, while for the 10/30 planting cultivars BRS 132, BRS 133 and BRS 134 had better performance. For later plantings, i.e., between 11/30 and $12 / 15$, the cultivars showing seeds with higher vigor were again BRS 132, BRS 133 and BRS 134.

The behavior of the physiological quality characteristics of seeds, as a function of sowing season for each cultivar and cropping season, in terms of percentage of normal seedlings in the germination (first count and final count) and accelerated aging tests, is illustrated, respectively, in Figures 2, 3 and 4. Regression analysis of data allowed quadratic type equations to be adjusted with a maximum point for each cultivar. In general, considering the three variables, the best sowing season for FT- Estrela was 25 days after 10/15, i.e., 11/9; 11/20 for BR 16; 11/11 for BRS 134 and 11/27 for BRS 132, indicating that the most favorable sowing season for the pro- duction of seeds with high germination and vigor was between $11 / 9$ and $11 / 27$ for the 1998/99 cropping season. For the second cropping season, the regression analysis also revealed a quadratic behavior of the equations, the sowing season in which the variables expressed maximum performance in terms of percentage of normal seedlings was 19 days for cultivar FT- Estrela, i.e., 11/03; 11/17 for BR 16; 11/18 for BRS 134 and 11/20 for BRS 132.

In the case of cultivar BRS 133, data partitioning revealed a non significant effect $(P>0.05)$ in the regression analysis, for both cropping seasons, indicating greater stability with respect to the production of better quality seeds in the different sowing dates evaluated.

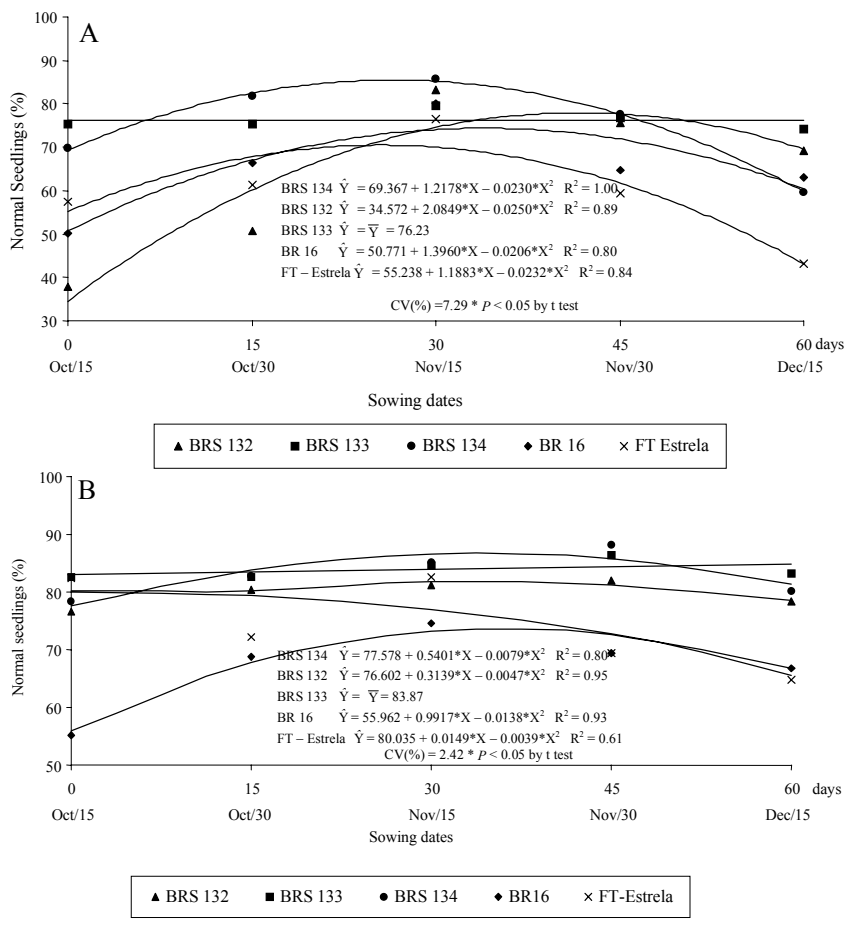

Figure 2 - Normal seedling percentages, obtained for the first count of the seed germination test of five soybean cultivars, for five sowing dates, during the 1998/99 (A) and 1999/00 (B) cropping seasons.

Table 4 - Totals of fungi and bacteria percentages, obtained for the seed health test of seeds of five soybean cultivars, for five sowing dates, in the 1998/99 and 1999/00 cropping seasons.

\begin{tabular}{|c|c|c|c|c|c|c|c|c|c|c|c|c|}
\hline \multirow{3}{*}{ Cultivar } & \multicolumn{5}{|c|}{ 1998/99 Cropping season } & \multicolumn{7}{|c|}{ 1999/00 Cropping season } \\
\hline & \multicolumn{5}{|c|}{ Sowing date ${ }^{1}$} & Mean & \multicolumn{5}{|c|}{ Sowing date ${ }^{1}$} & \multirow[t]{2}{*}{ Mean } \\
\hline & $10 / 15$ & $10 / 30$ & $11 / 15$ & $11 / 30$ & $12 / 15$ & & $10 / 15$ & $10 / 30$ & $11 / 15$ & $11 / 30$ & $12 / 15$ & \\
\hline BRS 132 & $20.00 \mathrm{a}$ & $9.33 \mathrm{a}$ & $0.33 \mathrm{a}$ & $5.00 \mathrm{a}$ & $20.33 \mathrm{~b}$ & 11.00 & $1.67 \mathrm{a}$ & $0.67 \mathrm{a}$ & $1.33 \mathrm{a}$ & $1.33 \mathrm{a}$ & $1.00 \mathrm{a}$ & 1.20 \\
\hline BRS 133 & $13.33 \mathrm{~b}$ & $1.67 \mathrm{~b}$ & $5.00 \mathrm{a}$ & $7.00 \mathrm{a}$ & $12.33 \mathrm{~b}$ & 7.87 & $5.00 \mathrm{a}$ & $0.33 \mathrm{a}$ & $0.33 \mathrm{a}$ & $1.00 \mathrm{a}$ & $2.33 \mathrm{a}$ & 1.80 \\
\hline BRS 134 & $7.33 \mathrm{~b}$ & $0.33 \mathrm{~b}$ & $0.67 \mathrm{a}$ & $5.00 \mathrm{a}$ & $30.00 \mathrm{a}$ & 8.67 & $7.00 \mathrm{a}$ & $0.00 \mathrm{a}$ & $0.00 \mathrm{a}$ & $0.33 \mathrm{a}$ & $1.67 \mathrm{a}$ & 1.80 \\
\hline BR 16 & $20.67 \mathrm{a}$ & $15.33 \mathrm{a}$ & $0.67 \mathrm{a}$ & $11.67 \mathrm{a}$ & $29.00 \mathrm{a}$ & 15.47 & $5.33 \mathrm{a}$ & $5.00 \mathrm{a}$ & $2.67 \mathrm{a}$ & $1.00 \mathrm{a}$ & $0.33 \mathrm{a}$ & 2.87 \\
\hline FT-Estrela & $11.00 \mathrm{~b}$ & $9.33 \mathrm{a}$ & $7.00 \mathrm{a}$ & $13.00 \mathrm{a}$ & $28.33 \mathrm{a}$ & 13.73 & $3.67 \mathrm{a}$ & $1.00 \mathrm{a}$ & $3.33 \mathrm{a}$ & $2.33 \mathrm{a}$ & $1.33 \mathrm{a}$ & 2.33 \\
\hline Mean & 14.47 & 7.20 & 2.73 & 8.33 & 24.00 & & 4.53 & 1.40 & 1.53 & 1.20 & 1.33 & \\
\hline C.V. $(\%)$ & & & 24.47 & & & & & & 8.37 & & & \\
\hline
\end{tabular}

${ }^{1}$ Means followed by a common letter, in each column, belong to the same group, according to the Scott-Knott (1974) clustering criterion, at $5 \%$. 

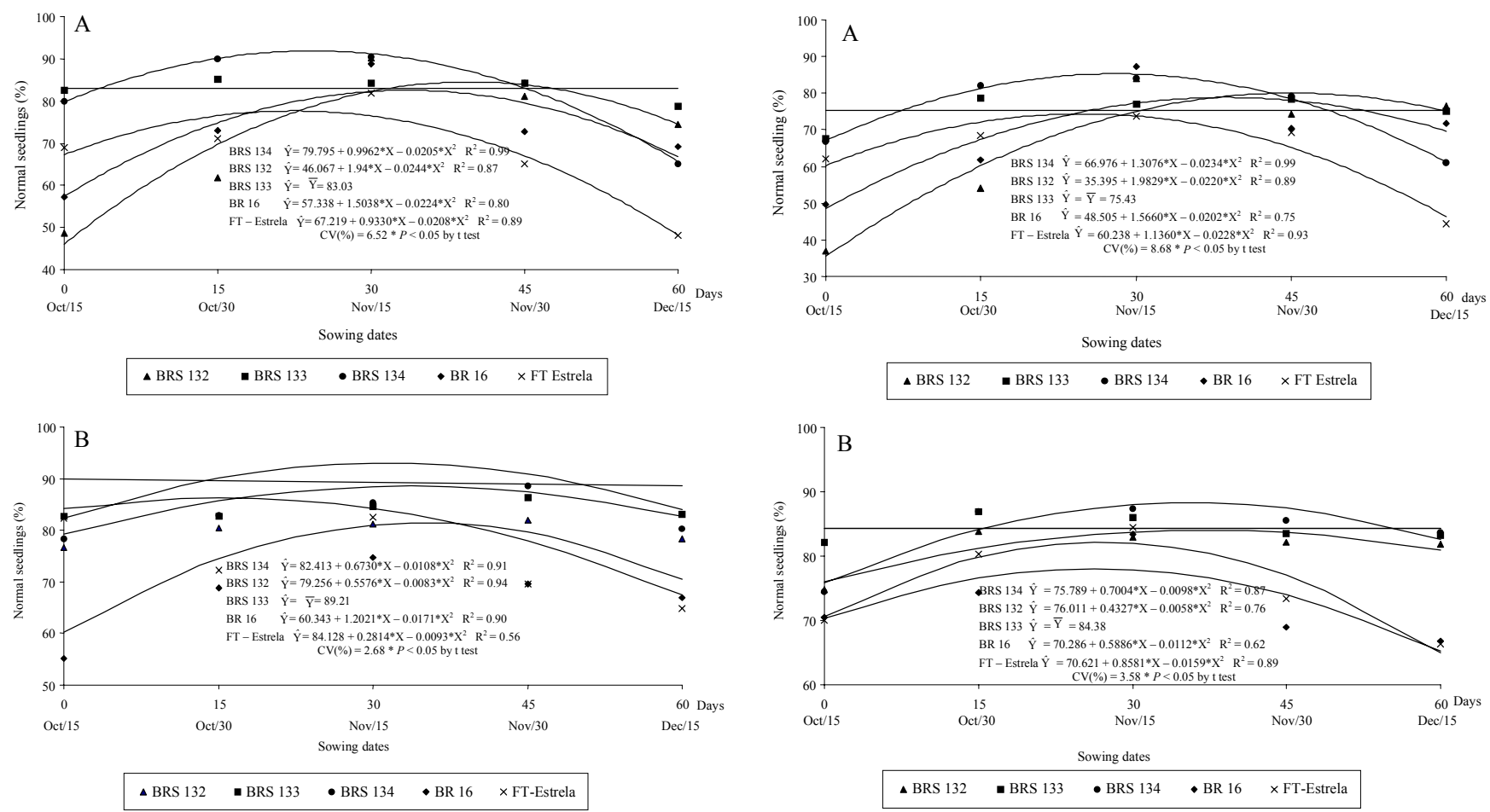

Figure 3 - Normal seedling percentages, obtained for the final count of the seed germination test of five soybean cultivars, for five sowing dates, during the 1998/99 (A) and 1999/ 00 (B) cropping seasons.

Cultivars BRS 134 and BRS 133, within the sowing period from $10 / 15$ to $11 / 30$, yielded the greatest percentages of normal seedlings in the germination and accelerated aging tests, in the 1998/99 cropping season. In the 1999/00 cropping season, the same cultivars had the best germination and vigor results, for all sowing seasons (Figures 2, 3 and 4).

Since the Maringá region has relatively high temperatures during the cropping season, it has been considered as medially favorable for soybean seed production in the State of Paraná (Costa et al., 1992). However, the results here in obtained indicate the possibility of obtaining good quality seeds if sowing is carried out in November.

Either advancing the sowing date or delaying the planting season were detrimental to the sanitary quality of soybean seeds produced in Maringá, during 1998/99, allowing quadratic regression equations to be adjusted (Figure 5A). The date of minimum fungi and bacteria contamination and the function minimum were, respectively: for cultivar FT-Estrela, 20 days after $10 / 15$ and $6.45 \%$; 22 days and $7.67 \%$ for BRS 134; 28 days and $5.21 \%$ for BR 16 ; 29 days and $5.74 \%$ for BRS 133; and 30 days and $1.58 \%$ for BRS 132. For the first cropping season the most favorable time for obtaining seeds with better sanitary quality was defined between $11 / 5$ and $11 / 15$. For the second cropping season, the analysis of variance revealed effect only for sowing seasons. Within this context, a quadratic regression equation was adjusted for the total percentage

Figure 4 - Normal seedling percentages, obtained for the accelerated aging test of seeds of five soybean cultivars, for five sowing dates, during the 1998/99 (A) and 1999/00 (B) cropping seasons.
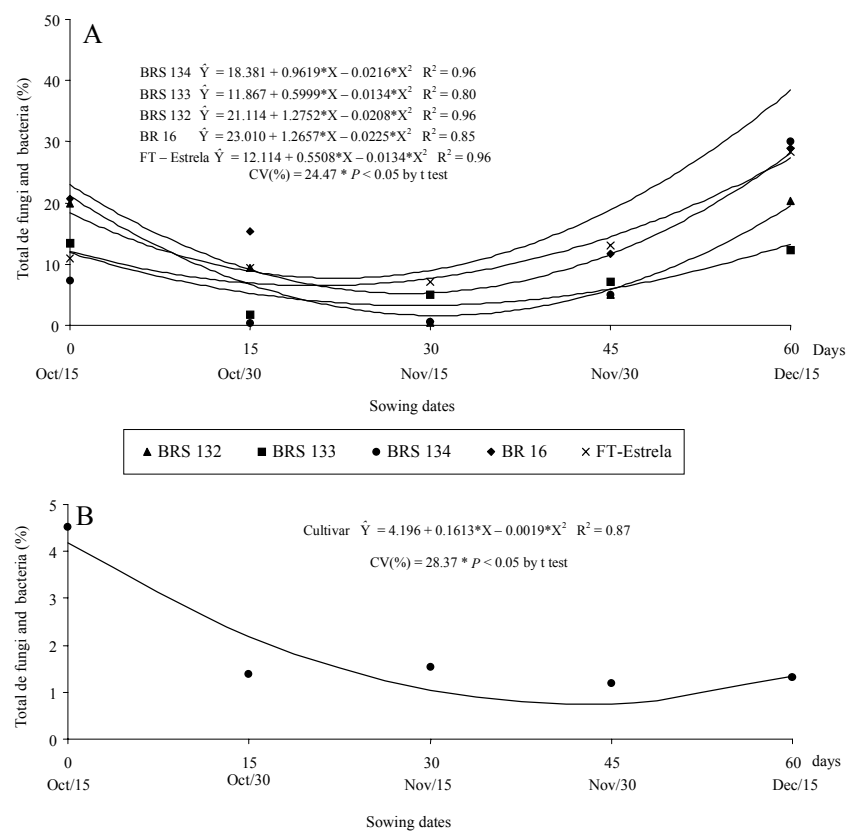

Figure 5 - Total of fungi and bacteria, percentages, obtained for the seed health test of seeds of five soybean cultivars, for five sowing dates, during the 1998/99 (A) and 1999/ 00 (B) cropping seasons.

of fungi and bacteria, as a function of the sowing season, considering the mean obtained for the five evaluated cultivars (Figure 5B), with a minimum point 42 days after the $10 / 15$ sowing date, and a function minimum of $0.78 \%$. 
Table 5 - Incidence of microorganisms on seeds of five soybean cultivars, for five sowing dates, during the 1998/99 and 1999/00 cropping seasons. 
The variation observed for this characteristic agrees with the results obtained for the evaluation of the physiological quality of seeds (Figures 2, 3 and 4), indicating that sowing in November yelds not only more vigorous seeds, but also lower rates of seed infection by pathogenic microorganisms (Figure 5). Similar results were obtained by Val et al. (1985).

Advancing the soybean sowing date to mid-October shifted full maturation to February and March for most cultivars, a period characterized by high precipitation (Figure 1). This certainly was detrimental to seed quality and favored the incidence of pathogens (Table 4 and Figure 5).

A separate analysis of the main pathogens present on the seeds provided more detailed information about the incidence of the main pathogens in each sowing season, allowing for more specific inferences to be made about their relative importance (Table 5). The main genera of fungi isolated and identified in this evaluation were: Aspergillus sp., Cercospora kikuchii, Colletotrichum dematium, Fusarium semitectum and Phomopsis sp. High incidence of bacteria in the seeds was also observed, especially in the last sowing date of the 1998/99 cropping season. Among the microorganisms evaluated, there was a predominance of the genera Aspergillus sp. and Colletotrichum dematium for the 10/15 sowing, with incidence means of 3.87 and $3.66 \%$, respectively, and of Fusarium semitectum and Aspergillus sp. in the latest planting date (12/15), with means of 7.93 and $7.27 \%$, respectively, for the 1998/99 cropping season.

During the second cropping season (1999/00), the incidence of pathogens on seeds was much lower than in the previous year (Table 5), favoring the production of better quality seeds (Tables 2 and 3). The highest means of infection by microorganisms occurred in the earliest sowing date (10/15), because of the predominance of Cercospora kikuchii and Fusarium semitectum, with means of 1.87 and $1.13 \%$, respectively. The other pathogens showed very reduced infection indices in the soybean cultivar seeds, along the different sowing dates and cropping seasons. Cultivars BRS 133 and BRS 134 can be considered promising for obtaining better quality seeds, for the evaluated sowing dates. Sowing in the month of November was favorable for obtaining seeds with better physiological and sanitary quality in Maringá, PR.

\section{REFERENCES}

BRASIL. Ministério da Agricultura e Reforma Agrária. Regras para análise de sementes. Brasília: DNDV; SNAD; CLAV, 1992. 365p.
COSTA, N.P.; PEREIRA, L.A.G.; FRANÇA NETO, J.B.; HENNING, A.A. Zoneamento ecológico do Estado do Paraná para a produção de sementes de cultivares precoces e soja. Londrina: EMBRAPA, CNPSo, 1992. 28p. (Boletim de Pesquisa, 2).

COSTA, N.P.; FRANÇA NETO, J.B.; HENNING, A.A.; KRZYZANOWSKI, F.C.; CABRAL, N.T.; MENDES, M.C. Efeito da época de semeadura sobre a qualidade fisiológica de sementes de soja no Estado do Mato Grosso. Revista Brasileira de Sementes, v.17, p.107$112,1995$.

DELOUCHE, J.C. Physiological changes during storage that affect soybean seed quality. In: SINCLAIR, J.B.; JACKOBS, J.A. (Ed.) Soybean seed quality and stand establishment. Urbana: Intsoy, 1982. p.57-66. (Intsoy, 22).

FEHR, W.R.; CAVINESS, C.E.; GURMOOD, D.T.; PENNINGTON, J.S. Stage of development description for soybean, Glycine max (L.) Merrill. Crop Science, v.11, p.929-931, 1971.

FRAGA, A.C. Determinação da maturação fisiológica das sementes de soja e de outras características agronômicas da soja, em três épocas de semeadura. Viçosa: UFV, 1980. 47p. (Dissertação - M.S.)

GOMES, K.A.; GOMES, A.A. Statistical procedures for agricultural reserch. New York: John Wiley \& Sons, 1984. 680p.

GOULART, A.C.P. Fungos em sementes de soja: detecção e importância. Dourados: EMBRAPA, CPAO, 1997. 58p. (Documentos, 11).

GREEN, D.E.; PINNEL, C.L.; CAVANAN, L.E.; WILLIANS, L.F. Effect of planting date and maturity date on soybean seed quality. Agronomy Journal, v.57, p.165-168, 1965.

HENNING, A.A. Patologia de sementes. Londrina: EMBRAPA, CNPSo, 1994. 43p. (Documentos, 90).

FUNDAÇÃO INSTITUTO AGRONÔMICO DO PARANÁ. Cartas climáticas básicas do Estado do Paraná. Londrina: IAPAR, 1987. 35p.

MARCOS FILHO, J. Produção de sementes de soja. Campinas: Fundação Cargill, 1986. 86p.

MARCOS FILHO, J. Teste de envelhecimento acelerado. In: KRZYZANOWSKI, F.C.; VIEIRA, R.D.; FRANÇA NETO, J.B. Vigor de sementes: conceitos e testes. Londrina: Abrates, 1999. p.3/1-3/24.

MELHORANÇA, A.L.; MESQUITA, A.N. Efeito do espaçamento e épocas de semeadura sobre o rendimento e caraterísticas agronômicas da soja em Dourados, MS. Pesquisa Agropecuária Brasileira, v.17, p.729-732, 1982.

NAKAGAWA, J.; ROSOLEM, C.A.; MACHADO, J.R. Épocas de semeadura da soja. I. Efeitos na produção de grãos e nos componentes da produção. Pesquisa Agropecuária Brasileira, v.18, p.1187-1198, 1983.

PARANÁ (Estado). Secretaria de Estado da Agricultura. Normas de produção de sementes, básica, registrada, certificada e fiscalizada. Curitiba: Empresa Paranaense de Classificação de Produtos, 1986. 130p.

ROCHA, V.S.; OLIVEIRA, A.B.; SEDIYAMA, T.; GOMES, J.L.L.; SEDIYAMA, C.S.; PEREIRA, M.G. A qualidade da semente de soja. Viçosa: UFV, 1996. 76p. (Boletim, 188).

SCOTT, A.; KNOTT, M. Cluster-analysis method for grouping means in analysis of variance. Biometrics, v.30, p.507-512, 1974.

TEKRONY, D.M.; EGLY, D.B.; PHILLIPS, A.D. Effects of field weathering on the viability and on vigor of soybean seed. Agronomy Journal, v.72, p.749-753, 1980.

VAL, W.M.C.; GAUDENCIO, C.A.; GARCIA, A. Ensaio sobre época de plantio. In: EMPRESA BRASILEIRA DE PESQUISA AGROPECUÁRIA. Resultados da pesquisa de soja, 1984/85. Londrina: EMBRAPA, CNPSo, 1985. p.393-396. 